\title{
"Anti-crisis development strategies of insurance companies in Ukraine and Poland in the context of COVID-19"
}

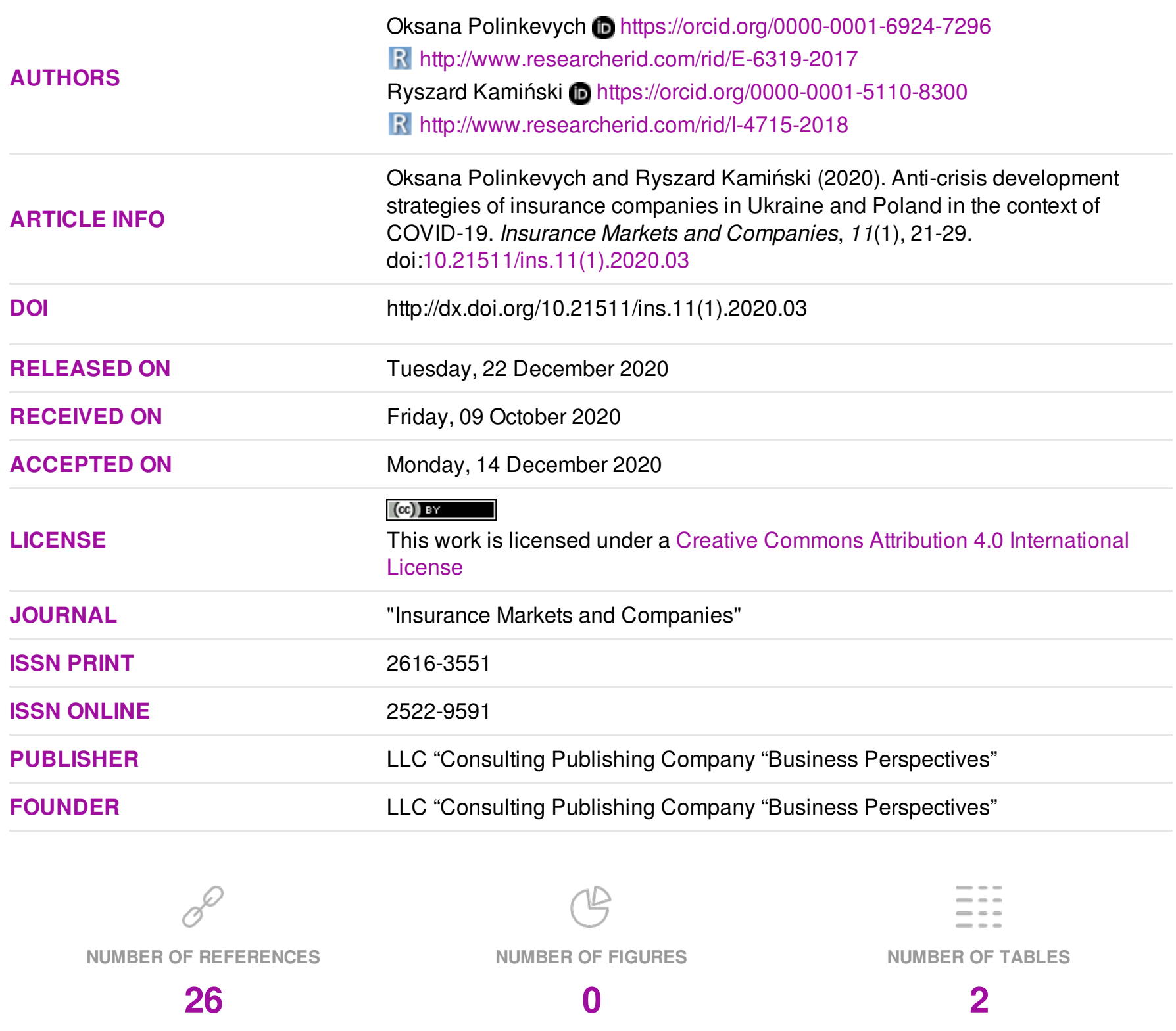

(c) The author(s) 2022. This publication is an open access article. 


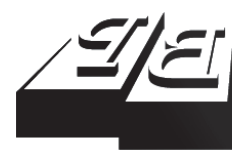

\section{BUSINESS PERSPECTIVES}

(O)

LLC "CPC "Business Perspectives" Hryhorii Skovoroda lane, 10 Sumy, 40022, Ukraine www.businessperspectives.org

Received on: $9^{\text {th }}$ of October, 2020 Accepted on: $14^{\text {th }}$ of December, 2020 Published on: $22^{\text {nd }}$ of December, 2020

(C) Oksana Polinkevych, Ryszard Kamiński, 2020

Oksana Polinkevych, Doctor of Economics, Professor, Professor of the Department of Tourism, Hotel and Catering Industry, Lutsk National Technical University, Ministry of Education and Science of Ukraine Lutsk, Ukraine. (Corresponding author)

Ryszard Kamiński, Doctor of Economics, Professor, Professor of the Department of Economics, Adam Mickiewicz University in Poznan, Ministry of Science and Higher Education, Poznan, Poland.

\section{ANTI-CRISIS DEVELOPMENT STRATEGIES OF INSURANCE COMPANIES IN UKRAINE AND POLAND IN THE CONTEXT OF COVID-19}

\begin{abstract}
Given the growing threats to the financial sustainability of businesses during the COVID-19 period, anti-crisis development strategies are the basis for ensuring successful operation and maintaining competitiveness in the markets. Insurance companies formulate and implement anti-crisis strategies in accordance with the requirements of the circular economy. Thus, the purpose of this study is to identify the main anti-crisis development strategies that insurance companies adhere to during COVID-19. The features of strategies that existed before the pandemic and were formed during the pandemic are identified. Tourism and hotel and catering business is an activity that considers the conditions of the circular economy. It is in this industry that the highest risks arise during the period of COVID-19. An anti-crisis development strategy of insurance companies during a period of pandemics and crises is understood as a tool for resolving contradictions in the development of a company in the event of a crisis or its threat. Moreover, the development process of the insurance company is inevitable, given the manifestations of the circular economy. As a result, insurance companies changed and consolidated anti-crisis development strategies during COVID-19. The newly created concentrating effort strategy combined the strategy of long-term planned changes and the strategy of balancing the interests of the insurance company and stakeholders. Instead, new strategies have emerged to innovate and maintain an adequate level of financial sustainability. It is especially worth highlighting the marketing strategy that ensures the image of insurance companies.
\end{abstract}

Keywords

anti-crisis strategy, development, insurance companies, risk, crisis, COVID-19, travel business, hotel and catering business, image, interest balancing

JEL Classification

G01, G22, H12

\section{INTRODUCTION}

Competition in global markets is constantly increasing, and companies are using new innovative solutions to expand their influence. All this leads to the fact that for a quick and timely response to the competitors' actions, the management and top management of a company must constantly analyze development strategies and periodically revise them. Insurance companies are no exception, which have to adapt their strategies to market demands during pandemics and crises. It should be noted that insurance companies are forced to quickly adapt to the crisis and changes, bearing in mind customers' capabilities and demands. Some see this as a path to development, others as a path to degradation and bankruptcy. The COVID-19 pandemic has become a test for the insurance market. Insurance companies are forced to develop anti-crisis strategies and change approaches to the provision of services. Accordingly, new types of services have appeared in the insurance market that are capable of ensuring the financial stability of 
insurance companies not only in the domestic but also in the international market. The need to develop anti-crisis strategies is due to the fact that the losses of insurers from COVID-19 are growing rapidly. The most vulnerable are travel companies, hotels and restaurants and healthcare. Insurance premiums for this group of companies are significant. This violates the financial stability of insurance companies, which introduces an imbalance in the development of the insurance market. Anti-crisis development strategies will contribute to the sustainability of insurance companies and reduce the negative impact of COVID-19.

\section{LITERATURE REVIEW}

Richter and Wilson (2000) analyzed the dangers of pandemic risk and described how insurance policies and scenario analysis were used to build resilience to emergencies in a crisis. The authors concluded that, as long-term investors, insurers must advance sustainability through capital adequacy and liquidity, coupled with limiting risk accumulation. Scenario analysis is important both for establishing and assessing exposure to risk in a changing environment. It can be improved by using reverse stress tests and examining the impact of controversial contract terms on changing public perceptions. Business disruption is not an insurance risk if it is triggered by deterrent actions to manage the global pandemic. In this regard, insurers need to improve policies and focus on strengthening harmonization, transparency and compliance. The consequences of the pandemic can have a significant impact on people's lives and well-being, and losses from insurance liabilities will be small compared to those arising with the development of the financial market (Richter \& Wilson, 2000).

Holliday et al. (2020) noted that many examples of innovation have emerged in the insurance market since the beginning of the COVID-19 pandemic. In the Philippines, FWD Public Insturance Company Limited has added medical care to life insurance policyholders diagnosed with COVID-19, as well as additional coverage for funeral expenses if an insured died of the virus. In Ghana, life insurance has launched the Pru Covered-19 add-on, which is automatically available to all customers. It includes helping diagnose and hospitalizing a person or any family member diagnosed with COVID-19, as well as a one-time payment in the event of the death. Some companies are now offering a discount by providing one month of free coverage (that is 13 months of coverage at a price of 12). In countries like India, this is linked to insurance regulation, while in other markets it is voluntary for insurance companies. For example, some US insurance companies, such as State Farm, provide cash rebates that are often calculated as a percentage of premiums paid by policyholders. In the United Arab Emirates, Beema offers potential customers free car insurance for one month. In addition, in the United States, in response to COVID-19, Next Insurance has offered digital insurance targeted at SMEs (general and professional liability, commercial auto insurance with a $25 \%$ discount on premium) (Holliday et al., 2020, p. 11).

Rau (2000) noted that the costs of the crisis caused by COVID-19 are a burden on health insurance companies. Medical insurance company Techniker Krankenkasse is forced to increase its authorized capital due to additional premiums. Government support should be an important area. Private health insurance may also get more expensive. Private health insurers are forced to increase insurance premiums. The private health insurance association Private Krankenversicherung Vergleich expects premium rates to rise by $8.1 \%$, with Debeka even intending to rise them by $17.6 \%$ from January 17 (Rau, 2020).

Pro-Consulting investigated Ukraine's health insurance market from 2016 to 2019. The company's analysts have identified the main players in the Ukrainian health insurance market and their competitive advantages. It is established that the number of insurance companies in the Ukrainian market is decreasing. The problems of the health insurance market include: economic instability in the country; lack of significant government control in the insurance market, since there may be a monopoly on the market, which can lead to uncontrolled pricing of services; low solvency of the population, because not every Ukrainian can afford to buy insurance; low awareness of the pop- 
ulation in the usefulness of insurance contracts. Thus, the promotion of insurance services among the population and the interpretation of the advisability of obtaining insurance coverage are becoming relevant (Horyslavets et al., 2018). It has been established that prices for health insurance services vary in each company. The price of health insurance depends on the amount of payments upon the occurrence of an insured event. The price also depends on the list of risks in the insurance program, the range of additional services, the region of service, the client's health status and age, etc. (Yermoshenko \& Trynchuk, 2016). Currently, the situation in the insurance market tends to increase the amount of insurance premiums. Bearing in mind the experience of European countries, Ukraine wants to introduce compulsory health insurance. And the reform of compulsory health insurance has been considered for a long time. Ukraine plans to introduce the British insurance model, according to which insurance will be financed from taxes paid not only by legal workers, but also by those who receive "shadow" wages.

Ostrowska-Dankiewicz and Simionescu (2020), Dankiewicz and Simionescu (2020) consider the relationship between the insurance market and macroeconomic indicators, while Kaigorodova et al. (2018) identify the features and patterns of development, formation, use and regulation of investment potential of insurance companies in modern economic conditions.

Successful investment activities of insurance companies are important from two perspectives. First, it is the basis for ensuring the financial stability of insurers (Kozmenko \& Roienko, 2013). Second, the investment resources accumulated by insurers are among the sources of the state's economic growth. Increasing the stability of insurance companies is a particularly important issue that is closely related to risk assessment (Khovrak \& Petchenko, 2015; Kozmenko \& Oliynyk, 2015; Pyrkova et al., 2018; Tsvetkova et al., 2019) and is gaining special importance in the COVID-19 pandemic.

Chvertko and Demchenko (2018) identified the risks that have developed in the field of tourism and hotel and catering business. They noted that there are many risks involved in their activities, so there is a need for insurance coverage that insurance companies can provide.

\section{GENERALIZATION OF MAIN STATEMENTS}

The study aims to determine the main anti-crisis development strategies that insurance companies adhere to during COVID-19, thereby achieving financial sustainability.

Insurance companies are forced to quickly adapt to the crisis and changes, taking into account the capabilities and needs of customers. It is worth agreeing that the COVID-19 pandemic has become a test for the Ukrainian insurance market. On the one hand, people have become more interested in personal insurance protection, namely voluntary health insurance (VHI) policies, specialized COVID-19 insurance policies, and life insurance. On the other hand, some corporate clients suffer from quarantine and reduce costs. The crisis forces everyone to quickly respond to changes, adapt to constraints, change business models and plans for the current and future years. It should be noted that the insurance market approached the current crisis better prepared than the crises of 2008-2009 or 2014-2015. In addition, although 2019 was turbulent, it turned to be quite effective for the insurance industry.

It is worth agreeing with Richter and Wilson (2000), who argue that scenarios need to be developed to improve the sustainability of insurance companies. According to Mind, the reliability rating of Ukrainian insurance companies, which is compiled according to the financial statements for the previous year, the first places in the rating are occupied by subsidiaries of international financial groups with German, French and Canadian roots.

Table 1 shows that the rate of financial stability is above $50 \%$ for insurance companies established by foreign beneficiaries, with the exception of European Travel Insurance and the Ukrainian Insurance Group. Insurance companies in the Ukrainian market receive a significant share of their income from Comprehensive car insurance, except liability. However, the share of travel insurance services reaches $64.6 \%$ in European Travel 
Table 1. Rating of Ukrainian insurance companies in 2017-2019*

\begin{tabular}{|c|c|c|c|c|c|c|c|c|}
\hline \multirow{3}{*}{ Insurance company } & \multirow{2}{*}{\multicolumn{3}{|c|}{ Rating, points }} & \multirow{3}{*}{ Beneficiary } & \multicolumn{3}{|c|}{$\begin{array}{c}\text { Business model of an insurance } \\
\text { company in } 2019, \%\end{array}$} & \multirow{3}{*}{$\begin{array}{c}\text { Financial } \\
\text { stability } \\
\text { index, \% }\end{array}$} \\
\hline & & & & & \multirow[b]{2}{*}{ Tourism } & \multirow{2}{*}{$\begin{array}{c}\text { Comprehensive car } \\
\text { insurance except } \\
\text { liability }\end{array}$} & \multirow[b]{2}{*}{ Health } & \\
\hline & 2017 & 2018 & 2019 & & & & & \\
\hline $\begin{array}{l}\text { UNIQA Insurance } \\
\text { Company }\end{array}$ & 3.0 & 4.5 & 4.5 & $\begin{array}{c}\text { UNIQA Internationale } \\
\text { Beteiligungs-Vervaltungs } \\
\text { GmbH (Austria) }\end{array}$ & 1.3 & 35.5 & 28.9 & 52.5 \\
\hline ARX & - & 4.5 & 4.5 & $\begin{array}{l}\text { Fairfax Financial Holdings } \\
\text { Limited (Canada) }\end{array}$ & 2.1 & 58.5 & 12.3 & 62.8 \\
\hline TAS Insurance Group & 3.0 & 4.0 & 4.0 & Individuals & 5 & 7 & 19.5 & 21.8 \\
\hline Colonnade Ukraine & 5.0 & 4.0 & 4.0 & $\begin{array}{l}\text { Fairfax Financial Holdings } \\
\text { (Luxembourg) }\end{array}$ & 0 & 25.6 & 36.5 & 82.9 \\
\hline $\begin{array}{l}\text { Insurance Company } \\
\text { Kniazha }\end{array}$ & 3.5 & 4.0 & 4.5 & $\begin{array}{l}\text { AG Wiener Versicheru } \\
\text { VIENNA INSURANCE } \\
\text { GROUP (Austria) }\end{array}$ & 19.7 & 16.2 & 8.6 & 81.9 \\
\hline $\begin{array}{l}\text { VUSO Insurance } \\
\text { Company }\end{array}$ & 3.0 & 4.0 & 4.0 & Individuals & 15.3 & 26.9 & 5.9 & 53.2 \\
\hline $\begin{array}{l}\text { Ukrainian Insurance } \\
\text { Group }\end{array}$ & 3.5 & 4.0 & 4.5 & ATBIH GmbH (Austria) & 0 & 38.3 & 11 & 42.1 \\
\hline $\begin{array}{l}\text { INGO Insurance } \\
\text { Company }\end{array}$ & 3.0 & 4.0 & 4.5 & Individuals & 2.1 & 27.1 & 21.6 & 55.2 \\
\hline $\begin{array}{l}\text { PZU Ukraine Insurance } \\
\text { Company }\end{array}$ & 2.5 & 4.0 & 4.0 & $\begin{array}{l}\text { Powszechny Zaklad } \\
\text { Ubezpieczen SA (Poland) }\end{array}$ & 15.7 & 22.3 & 8.2 & 51.2 \\
\hline Arsenal Insurance & 2.5 & 4.0 & 4.5 & Individuals & 0.9 & 48.5 & 3.4 & 53.1 \\
\hline $\begin{array}{l}\text { Universalna Insurance } \\
\text { Company }\end{array}$ & 3.0 & 4.0 & 4.5 & $\begin{array}{l}\text { Fairfax Financial Holdings } \\
\text { Limited (Canada) }\end{array}$ & 5 & 39.1 & 11.5 & 59.7 \\
\hline $\begin{array}{l}\text { Persha Insurance } \\
\text { Company }\end{array}$ & 2.0 & 3.5 & 4.0 & Individuals & 6.4 & 11 & 0.6 & 76 \\
\hline $\begin{array}{l}\text { European Travel } \\
\text { Insurance }\end{array}$ & 4.0 & 3.5 & 4.0 & $\begin{array}{l}\text { Euroins Insurance Group } \\
\text { (Bulgaria) }\end{array}$ & 64.6 & 0 & 0 & 48.5 \\
\hline
\end{tabular}

Note: Parameter scores: 5 - high level of reliability for customers, 4 - stable level of attractiveness to customers, 3 - satisfactory level of attractiveness to customers, 2 - low level of attractiveness to customers, and 1 - catastrophic level of attractiveness to customers. * Compiled by the authors according to Kharlamov and Butenko (2017), Rating of insurance companies - 2018, and Rating of insurance companies - 2019.

Insurance, Insurance Company Kniazha has 19.7\%, PZU Ukraine Insurance Company 15.7\%, VUSO Insurance Company 15.3\%, Persha Insurance Company 6.4\%, Universalna Insurance Company 5\%, TAS Insurance Group 5\%, ARX 2.1\%, INGO Insurance Company 2.1\%, UNIQA Insurance Company $1.3 \%$, and Arsenal Insurance $0.9 \%$. In international insurance activities, much attention is paid to travel insurance abroad. Indeed, according to the World Tourism Organization, the share of international tourism in world GDP is 6\% and about $30 \%$ of world exports of services. In the near future, the number of international tourist visits is projected to increase from 582 million in 2014 to 1.8 billion in 2030 (Legislation of Ukraine, 2016).

The rating of insurance companies in Poland is compiled according to a different method, namely by the number of complaints and the complaint rate, which is determined by comparing the number of complaints to the insurance company on the market. The second indicator shows the level of customer satisfaction with the services of insurance companies.

According to it, the largest market share belongs to PZU S.A., STU Ergo Hestia S.A., and TuiR Warta S.A. As expected, the largest number of complaints to the Ombudsman concerns PZU S.A. However, if one compares their number with the market share (32-33\%), it turns out that the level of complaints for insurers in 20172019 is approximately average. The second largest insurance companies are STU Ergo Hestia S.A. (14.2-15\%) and TuiR Warta S.A. (13.5-14\%), which achieved much better results than PZU S.A. STU Ergo Hestia S.A., Concordia Polska TUW, Pocztowe TUW are the best insurance 
Table 2. Rating of Polish insurance companies in 2017-2019*

\begin{tabular}{|c|c|c|c|c|c|c|}
\hline \multirow[b]{2}{*}{ Insurance company } & \multicolumn{2}{|c|}{2017} & \multicolumn{2}{|c|}{2018} & \multicolumn{2}{|c|}{2019} \\
\hline & $\begin{array}{c}\text { Market } \\
\text { share }\end{array}$ & $\begin{array}{l}\text { Complaint } \\
\text { rate }\end{array}$ & $\begin{array}{c}\text { Market } \\
\text { share }\end{array}$ & $\begin{array}{c}\text { Complaint } \\
\text { rate }\end{array}$ & $\begin{array}{c}\text { Market } \\
\text { share }\end{array}$ & $\begin{array}{c}\text { Complaint } \\
\text { rate }\end{array}$ \\
\hline PZU S.A. & 33.3 & 47 & 33.2 & 51.3 & 32 & 47.3 \\
\hline STU Ergo Hestia S.A. & 13.7 & 33.9 & 14.2 & 35.5 & 15 & 36.6 \\
\hline TuiR Warta S.A. & 12.9 & 27.5 & 13.5 & 25.3 & 14 & 25.6 \\
\hline Concordia Polska TUW & - & 25.3 & 0.8 & 31.3 & 1.4 & 35.7 \\
\hline Pocztowe TUW & - & 46.3 & 0.4 & 25.0 & 2.5 & 27.5 \\
\hline TUZ TUW & 2.03 & 147.8 & 0.6 & 130 & 2 & 118 \\
\hline Link 4 TU S.A. & 2.18 & 98.1 & 2.7 & 106.3 & 2.6 & 124.2 \\
\hline Generali TU S.A & 4.63 & 114.3 & 3.7 & 101.6 & 3.7 & 64.9 \\
\hline AXA Ubezpieczenia TuiR S.A. & - & 129.5 & 5.0 & 80.8 & 5 & 66.2 \\
\hline TUW TUW & - & - & - & 63.3 & - & 86.7 \\
\hline
\end{tabular}

Note: * Compiled according to the data from Sulowski (2019), Wybór Kierowców $(2017,2018)$.

companies in 2019, while TuiR Warta S.A. and PZU S.A. have an average level. Pocztowe TUW has the lowest complaint rate. Customers evaluate the work of TUZ TUW, Link 4 TU S.A., Generali TU S.A. in 2018 and additionally AXA Ubezpieczenia TuiR S.A., TUW TUW in 2019 as the worst due to a significant number of complaints and a high complaint rate.

The COVID-19 pandemic has become a test for the insurance market. In the UK, insurance companies will pay travelers at least $£ 275$ million (about USD 340 million) due to the coronavirus epidemic. In March 2020, London stopped selling travel insurance to new customers. On September 15, 2020, Lloyd's of London confirmed its forecast, according to which the losses of the insurance industry from the COVID-19 pandemic amounted to USD 107 billion. On September 24, 2020, the High Court in London clarified the situation with insurers covering the risks of a pandemic. As of October 5, 2020, coronavirus was recognized as the main insurance risk of 2020. As of October 28,2020 , the publicly reported COVID-19-related losses of the world's largest reinsurance companies reached USD 23.7 billion. As of November 3, 2020, insurers' losses from coronavirus exceeded USD 100 billion. Only five markets in Central and Eastern Europe managed to get positive dynamics, namely: Latvia (+3.31\%), Serbia (+4.28\%), Slovenia $(+4.21 \%)$, and Romania and Lithuania - markets that managed to maintain the level of the first half of 2019 and actually increase their business volumes. In the first half of 2020, gross market premiums were 19.11 billion euros, which was $3.8 \%$ less than in 2019.
According to the Cabinet of Ministers, due to the epidemic, Ukraine's tourism industry will lose about UAH 40 billion. Shopping and entertainment centers (SEC) estimate their losses during the quarantine period at UAH 7 billion, and the tenants of SECs have lost more than UAH 50 billion in turnover. Against this background, there is a sharp demand for cyber insurance in the markets (Kaigorodova et al., 2020). According to one forecast, due to COVID-19, the cyber insurance sector will reach USD 230 billion by the end of 2020 , and its average annual growth rate will be $12 \%$. The Chinese were among the first to think about insuring businesses against "viral" risks. Back in February, Hainan Province launched a coronavirus-related business insurance program. The total coverage was RMB 12 million, equivalent to USD 1.7 million. Insurers will compensate for losses associated with the depletion of raw materials, personnel costs, the introduction of quarantine measures and other losses. Lloyd's, one of the oldest and most influential insurance and reinsurance organizations in the world, estimates that the expected coronavirus pandemic insurance and reinsurance claims could be USD 107 billion. Fitch Ratings said the insurance industry will face many claims and lawsuits from companies seeking compensation for damages caused by the pandemic. Moreover, it is impossible to predict the scope of these claims. Lloyd's and Fitch Ratings have approved warnings to exclude any risks associated with the coronavirus pandemic, which means that insurance and reinsurance companies will not compensate for losses directly caused by COVID-19. Lloyd's position has been confirmed by Fitch Ratings. According to Fitch's 
research, the pandemic was and remains a standard exception for risk reinsurance under BI (business interruption) contracts. Such a product covers possible losses from the forced termination of activities that may occur due to property damage (Kharlamov, 2020). The coronavirus outbreak has drawn global attention to health issues. It is not surprising that interest in voluntary health insurance policies is growing. Specialized programs begun to appear on the market to cover the risk of COVID-19.

\section{DISCUSSION}

Prior to the COVID-19 pandemic, insurance companies developed and implemented the following key anti-crisis development strategies:

1) A long-term planned change strategy. Anticrisis strategy is a function of duration and has certain limits of the nature of changes. This strategy is considered to be successfully implemented once the organization has entered sustainable operation and a steady state is planned. From this point of view, the anti-crisis development strategy can be seen as a means to achieve a specific goal, namely overcoming the crisis.

2) A strategy for balancing the interests of the insurance company and stakeholders. In both groups (individually or in combination), the level of significance of certain development areas is determined and the assessment is taken into account not only by the owners, but also by customers. For this, it is recommended to conduct SWOT analysis and TOWS analysis.

3) A risk management strategy. The risks can be divided into several groups: "flexa" risks, technical risks, and risks of social and civil responsibility to service users.

The anti-crisis strategy for the development of insurance companies during a period of pandemics and crises is understood as a tool for resolving contradictions in the development of a company in the event of a crisis or its threat. Since the quarantine came as a surprise to Ukrainian business, it led to changes in the formation of anti-crisis de- velopment strategies. No company was ready to terminate its activity almost completely for two months. Therefore, many economic sectors were in a big minus.

Thus, during the COVID-19 pandemic, insurance companies changed their approaches to the formation and implementation of basic anti-crisis development strategies:

1) An effort concentration strategy that combines a strategy of long-term planned changes and balancing the interests of the insurance company and stakeholders. The main priority is to find a balance of interests between the three participants in the process: owners, managers, and clients or stakeholders. Besides, it is worth developing a marketing strategy for managing the image of insurance companies, which should form a positive goodwill of the company (Polinkevych \& Kamiński, 2018).

2) An innovation strategy consisting in the development and implementation of new insurance services, risk compensation mechanisms, considering the specifics of pandemics and crises. These include cyber insurance and an overview of the risk management mechanisms associated with the coronavirus pandemic. That is, insurance and reinsurance companies must develop a mechanism to compensate for damages directly caused by COVID-19.

3) A strategy for maintaining a sufficient level of financial sustainability of insurance companies. In this context, the concept of financially sustainable development of an insurance company arises. The closer the company is to the center of the financially sustainable development zone, the more risks it may face, which is especially important during the COVID-19 period. The influence of one or more factors of the external or internal environment can cause deviations in the activities of the insurer and the variability of its transition to a higher level of development with an increase in financial sustainability. In addition, depending on the strength of the factor and the 
operating conditions of the company, this can lead to the termination of activities due to reduced financial sustainability and the lack of opportunities to resume or continue development in the same area with changes in some characteristics that will further affect the level of sustainability.

There are many views on this issue among scientific schools. However, previous studies did not compare insurance companies' anti-crisis strat- egies before and after the COVID-19 pandemic. In this study, the problem of delimiting strategies was first posed, and the term "anti-crisis development strategy" was introduced. In the process of developing anti-crisis development strategies, it is proposed to consider the tourism and hotel and catering business sector, since this sector is most sensitive to the COVID-19 pandemic and provokes the introduction of innovation in the insurance companies' development strategies.

\section{CONCLUSION}

When shaping and implementing anti-crisis strategies for the development of insurance companies, it is necessary to consider the following basic conditions, thanks to which they will be successfully implemented:

1) systematic and balanced decisions regarding changes in approaches to insurance;

2) considering the specifics of the emergence of risks, that is, depending on the type of economic activity, it is necessary to determine the needs and preferences of customers;

3) substantiating the feasibility of developing the direction of insurance of tourism and hotel and catering business as one of the most promising activities in a circular economy; and

4) innovation and speed of implementation of strategic changes in the activities of insurance companies.

The concept of anti-crisis strategy for the development of insurance companies during a period of pandemics and crises contains the following main elements:

1) a tool for resolving contradictions;

2) the process of development of the insurance company is inevitable given the manifestations of the circular economy; and

3) an increase in the number of crises or their threats, as well as pandemics at the national, regional and local levels.

Anti-crisis development strategies of insurance companies are changed and consolidated considering the specifics and risks that arise in the process of companies' work. Key strategies during the COVID-19 period include an effort concentration strategy, an innovation strategy, and a strategy for maintaining an adequate level of financial sustainability. These three strategies are core and partially combine the anti-crisis strategies that companies implemented before the COVID-19 pandemic. In particular, the first strategy combines two anti-crisis strategies, such as the strategy of long-term planned changes and the strategy of balancing the interests of the insurance company and stakeholders. It is important to develop a marketing strategy to manage the image of insurance companies, which should generate a positive goodwill. The risk management strategy is contained in the innovation strategy and provides for the development and implementation of new insurance services, risk compensation mechanisms, considering the specifics of pandemics and crises. Cyberinsurance and a mechanism for compensating losses directly caused by COVID-19 are interesting areas of insurance. It should also be noted that in the face of pandemics and crises, the financial sustainability of insurance companies is critical. The closer the company is to the center of the financially sustainable development zone, the more risks it may face, which is especially important during the COVID-19 period. 


\section{AUTHOR CONTRIBUTIONS}

Conceptualization: Oksana Polinkevych.

Data curation: Oksana Polinkevych, Ryszard Kamiński.

Formal analysis: Oksana Polinkevych, Ryszard Kamiński.

Funding acquisition: Oksana Polinkevych, Ryszard Kamiński.

Investigation: Oksana Polinkevych, Ryszard Kamiński.

Methodology: Oksana Polinkevych, Ryszard Kamiński.

Project administration: Oksana Polinkevych.

Resources: Oksana Polinkevych, Ryszard Kamiński.

Supervision: Oksana Polinkevych, Ryszard Kamiński.

Validation: Oksana Polinkevych, Ryszard Kamiński.

Visualization: Oksana Polinkevych, Ryszard Kamiński.

Writing: Oksana Polinkevych, Ryszard Kamiński.

\section{REFERENCES}

1. Chvertko, L. A., \& Demchenko, T. A. (2018). Strakhuvannia turystychnykh ryzykiv: problemy teorii ta praktyky [Travel risk insurance: problems of theory and practice]. Ekonomichni horyzonty-Economic horizons, 1(4), 67-75.

2. Dankiewicz, R., \& Simionescu, M. (2020). The insurance market in Romania: A macroeconomic and a microeconomic approach. Transformations in Business and Economics, 19(1), 248-261. Retrieved from http://www. transformations.knf.vu.lt/49/ article/thei

3. Holliday, S., Sherchan, P., \& Ebrahimi, S. (2020). COVID-19 and the Insurance Industry: Why a Gender-Sensitive Response Matters. International Finance Corporation. Retrieved from https://www.ifc.org/wps/wcm/ connect/eaebcd1f-5b9f-467eb6cf-b4d616842375/202006Women-Insurance-COVID19+B. pdf?MOD=AJPERES

4. Horyslavets, P., Plonka, M., \& Trynchuk, V. (2018). Experience marketing and its tools in promoting the insurance services. Innovative Marketing, 14(1), 4148. http://dx.doi.org/10.21511/ im.14(1).2018.05

5. Kaigorodova, G., Alyakina, D., Pyrkova, G., Mustafina, A., \& Trynchuk, V. (2018). Investment Activity of Insur- ers and the State Economic Growth. Montenegrin Journal of Economics, 14(4), 109-123. http://doi.org/10.14254/1800$5845 / 2018.14-4.8$

6. Kaigorodova, G., Mustafina, A., Pyrkova, G., Vyukov, \& Davletshina, L. M. (2020). Cyber Risks for Insurance Company. In S. Ashmarina, A. Mesquita, \& M. Vochozka (Eds.), Digital Transformation of the Economy: Challenges, Trends and New Opportunities (pp. 669-677). Springer, Cham. http://doi. org/10.1007/978-3-030-113674_64

7. Kharlamov, P. (2020). Strakhovka vs COVID: yak biznesu zakhystytysia vid epidemii i pandemii. I chomu strakhovi kompanii ne khochut kompensuvaty «koronavirusni» zbytky [Insurance vs COVID: how businesses protect themselves from epidemics and pandemics. And why insurance companies do not want to compensate for "coronavirus" losses]. (In Ukrainian). Retrieved from https://mind.ua/ publications/20211245-strahovka-vs-covid-yak-biznesu-zahistitisya-vid-epidemij-i-pandemij

8. Kharlamov, P., \& Butenko, O. (2017). Honka na vyzhyvannia: reitynh strakhovykh kompanii-2017 [Survival race: ranking of insurance companies-2017]. (In Ukrainian).
Retrieved from https://mind.ua/ publications/20172756-gonkana-vizhivannya-rejting-strahovih-kompanij-2017.

9. Khovrak, I. V., \& Petchenko, M. V. (2015). Estimating the level of financial safety in banking institutions. Actual Problems of Economics, 164(2), 347-354. Retrieved from http:// dspace.univd.edu.ua/xmlui/ handle/123456789/6851

10. Kozmenko, O., \& Oliynyk, V. (2015). Statistical model of risk assessment of insurance company's functioning. Investment Management and Financial Innovations, 12(2), 189-194. Retrieved from https://businessperspectives.org/images/ pdf/applications/publishing/ templates/article/assets/6780/ imfi_en_2015_02cont_Kozmenko.pdf

11. Kozmenko, O., \& Roienko, V. (2013). Evaluation and use of indicators of insurance companies' investment activities. Investment Management and Financial Innovations, 10(3), 98-105. Retrieved from https:// businessperspectives.org/media/ zoo/applications/publishing/ templates/article/assets/js/pdfjs/ web/5373

12. Legislation of Ukraine. (2016). Informatsiino-analitychni materialy do parlamentskykh slukhan na temu: "Rozvytok turystychnoi 
industrii yak instrument ekonomichnoho rozvytku ta investytsiinoi pryvablyvosti Ukrainy" [Information and analytical materials for the parliamentary hearings on the topic: "Development of the tourism industry as a tool for economic development and investment attractiveness of Ukraine"]. Retrieved from http:// komsport.rada.gov.ua/uploads/ documents/30566.pdf.

13. Mind. (2018). Reitynh strakhovykh kompanii - 2018: yak rynok strakhovykiv $v$ Ukraini vykhodyt iz zastoiu [Rating of insurance companies - 2018: how the market of insurers in Ukraine comes out of stagnation]. (In Ukrainian). Retrieved from https://mind.ua/ publications/20186445-rejtingstrahovih-kompanij-2018-yakrinok-strahovikiv-v-ukrayinivihodit-iz-zastoyu

14. Mind. (2019). Reitynh strakhovykh kompanii - 2019 [Rating of insurance companies - 2019]. (In Ukrainian). Retrieved from https://mind.ua/ publications/20198476-rejtingstrahovih-kompanij-2019

15. Ostrowska-Dankiewicz, A., \& Simionescu, M. (2020). Relationship between the insurance market and macroeconomic indicators in the EU member states. Transformations in Business and Economics, 19(3), 175187. Retrieved from http://www. transformations.knf.vu.lt/51/ article/rela

16. Polinkevych, O. \& Kamiński, R. (2018). Corporate image in behavioral marketing of business entities. Innovative Marketing, 14(1), 33-40. http://doi. org/10.21511/im.14(1).2018.04

17. Pro-Consulting. (2020). Analiz rynku medychnoho strakhuvannia Ukrainy 2020 rik [Analysis of the health insurance market of Ukraine 2020]. Retrieved from https://pro-consulting.ua/ua/ issledovanie-rynka/analiz-rynka-medicinskogo-strahovaniyav-ukraine-2020-god

18. Pyrkova, G., Kaigorodova, G., Mustafina, A., \& Alyakina, D.
(2018). Financial risks: Methodological approaches and management methods. Journal of Social Sciences Research, 5, 122-127. Retrieved from https:// www.arpgweb.com/pdf-files/ spi5.27.122.127.pdf

19. Rau, A. (2020). Corona brings health insurance companies to their financial limits. The Germany Eye. Saturday 5th December. Retrieved from https://thegermanyeye.com/ corona-brings-health-insurancecompanies-to-their-financiallimits-3873

20. Richter, A. \& Wilson, T.C. (2000). COVID-19: implications for insurer risk management and the insurability of pandemic risk. The Geneva Risk and Insurance Review, 45, 171-199. https://doi. org/10.1057/s10713-020-00054-Z

21. Sulowski, S. (2019). Najgorsze i najlepsze firmy ubezpieczeniowe w 2019 roku (In Polish). Retrieved from https://www. wyborkierowcow.pl/najgorsze-inajlepsze-firmy-ubezpieczeniowe-w-2019-roku/

22. Tsvetkova, L., Yurieva, T., Orlaniuk-Malitskaia, L., \& Plakhova, T. (2019). Financial intermediary and insurance companies: Assessing financial stability. Montenegrin Journal of Economics, 15(3), 189-204. http://doi.org/10.14254/18005845/2019.15-3.14

23. Unian. (2020). Strakhovyi rynok Tsentralnoi ta Skhidnoi Yevropy skorochuietsia cherez koronavirus [The insurance market in Central and Eastern Europe is shrinking due to the coronavirus]. (In Ukrainian). Retrieved from https://www.unian.ua/insurance/ strahoviy-rinok-centralnoji-tashidnoji-yevropi-v-1-pivrichchi2020-skorotivsya-na-3-8-noviniukrajini-ta-svitu-11208836.html

24. Wybór Kierowców. (2017). Najgorsze i najlepsze firmy ubezpieczeniowe w 2017 roku - RAPORT. (In Polish). Retrieved from https://www.wyborkierowcow. $\mathrm{pl} /$ najgorsze-i-najlepsze-firmyubezpieczeniowe-raport/
25. Wybór Kierowców. (2018). Najgorsze i najlepsze firmy ubezpieczeniowe w 2018 roku. (In Polish). Retrieved from https://www. wyborkierowcow.pl/najgorsze-inajlepsze-firmy-ubezpieczeniowe-w-2018-roku/

26. Yermoshenko, A., \& Trynchuk, V. (2016). Approaches to evaluating the quality of voluntary medical insurance services in Ukraine. Actual Problems of Economics, 183(9), 285-293. Retrieved from https://www.researchgate.net/ publication/308581824_Approaches_to_evaluating_the_ quality_of_voluntary_medical_ insurance_services_in_Ukraine 